\title{
A Renovation Proposal for Zero-Energy Houses: Outline of Building Planning and Evaluation of Thermal Environment
}

\author{
Soma Sugano ${ }^{1}$, Shingo Yamaguchi ${ }^{1}$, Yugo Tsuneoka ${ }^{1}$, Reina $\mathrm{Oki}^{1}$, Jun Nakagawa ${ }^{1}$, \\ Naoya Watanabe ${ }^{2}$, Tatsuhiro Kobayashi ${ }^{2}$, Shin-ichi Tanabe ${ }^{1}$, and Takashi Akimoto ${ }^{3}$ \\ ${ }^{1}$ Department of Architecture, Waseda University, 169-8555 Tokyo, Japan \\ ${ }^{2}$ Asahi Kasei Homes Corporation, 101-8101 Tokyo, Japan \\ ${ }^{3}$ Department of Architecture, Shibaura Institute of Technology, 135-8548 Tokyo, Japan
}

\begin{abstract}
Considering the effects of electricity shortages caused by natural disasters in Japan, residential energy efficiency is essential. In addition, excessive housing stocks in Japan have highlighted the importance of expertise in renovation methods for zero-energy houses (ZEHs). Therefore, we designed and built a ZEH as a refurbishment of steel-structure industrialized housing to acquire knowledge on ZEH design and renovation. The renovation uses a highly insulated volume against a low insulation volume, which is assumed to be an existing house. The space between the low-insulation wall facing the outside and the highinsulation wall surrounding the main living space functions as a sunroom and called a loggia. By opening and closing the inside and outside windows according to the season and time of day, the loggia functions as a passive system to reduce the air-conditioning load. In this paper, the outline of the building plan of the experimental house and the evaluation of the thermal environment are presented.
\end{abstract}

\section{Introduction}

The effects of electricity shortages caused by natural disasters in Japan have highlighted the importance of residential energy efficiency. In addition, excessive housing stocks in Japan have highlighted the importance of expertise in renovation methods for zero-energy houses (ZEHs) [1]. In the winter of 2017, a ZEH competition, titled ENEMANE House 2017, was held in Japan. This paper presents an overview of the building planning and evaluation of the thermal environment of the ZEH proposed by us in this competition.

\section{Research objectives}

We proposed a ZEH renovation method for existing industrialized houses to acquire knowledge on ZEH design. Following this, we constructed an actual size model house (hereafter referred to as the experimental house) and measured the indoor environment and energy efficiency.

\section{Architectural overviews}

Fig.1 shows the exterior and interior of the experimental house. Table 1 shows the outlines. This experimental house was designed as a refurbishment of steel structure industrialized housing from the 1970s. Furthermore, this design succeeded in reducing primary energy consumption. The BEI (Building Energy Index) value representing the ratio of the design's primary energy to the reference primary energy was 0.30 , and the highest BELS certification value (five stars) was obtained.

\subsection{Floor plan}

Fig.2 shows floor plan of the experimental house. While keeping the existing low-insulation wall as the outer wall, a new, highly insulated wall was inserted into the existing structure. The space between the low-insulation wall facing the outside air and the high-insulation wall surrounding the main living space functioned as a sunroom and was called a loggia.
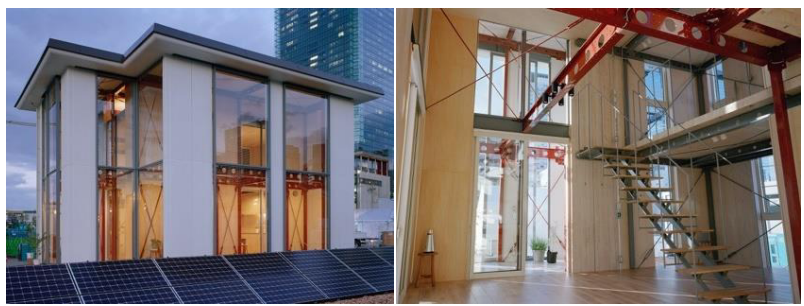

Fig.1 Exterior and interior of the experimental house

Table 1. Outlines of experimental house

\begin{tabular}{|c|c|c|c|c|}
\hline Location & Osaka & $\begin{array}{c}\text { Total floor } \\
\text { area }\left[\mathbf{m}^{\mathbf{2}}\right]\end{array}$ & total & 79.11 \\
\hline Main structure & Steel & & Living & 4.37 \\
\cline { 1 - 2 } $\begin{array}{c}\text { Number of } \\
\text { floors }\end{array}$ & 2 & \multirow{2}{*}{ Floor } & $\begin{array}{c}1 \mathrm{~F} \\
\text { height }[\mathbf{m}]\end{array}$ & 2.2 \\
\cline { 1 - 2 } $\begin{array}{c}\text { Building area } \\
{\left[\mathbf{m}^{2}\right]}\end{array}$ & 66.03 & & $\begin{array}{c}2 \mathrm{~F} \\
\text { room }\end{array}$ & 2.2 \\
\hline
\end{tabular}

\footnotetext{
* Corresponding author: sugano@tanabe.arch.waseda.ac.jp
} 


\subsection{Section}

Fig. 3 shows a section of the experimental house. The gap parallel to the roof between the existing roof and the high insulation volume behaves as an attic aerial layer. This space is connected to both the south and west loggias. The functions of the loggia and attic aerial layer will reduce the heat and air conditioning loads in the living areas via solar radiation and outside air.

\subsection{Construction of walls, floor, and ceiling}

Fig. 4 shows the arrangement of each member, and Table 2 shows the members' constitutions and performance values. The wall and ceiling of the outer skin for the existing houses consisted of ALC panels, and the windows were movable large windows fitted with a single glass pane in a steel sash. The high-insulation wall consisted of three kinds of walls and windows equipped with Low-E triple glass, which achieved a $U_{A}$ value of $0.35 \mathrm{~W} / \mathrm{m}^{2} \cdot \mathrm{K}$. The vacuum insulation wall used between the living room and the loggia was made from vacuum heat insulation material, sheet-type latent heat storage material, high-performance phenol foam, etc. This wall had a heat transmission coefficient of $0.05 \mathrm{~W} / \mathrm{m}^{2} \cdot \mathrm{K}$ with a thickness of $105 \mathrm{~mm}$.

\section{Operation of architecture}

\subsection{Loggia}

Fig. 5 shows seasonal operation of the loggia. By opening and closing the inside and outside windows according to the season and time of day, the loggia functions as a passive system to reduce the air conditioning load. In summer, by opening the windows on the outdoor side, the roof becomes an eaves and prevents direct sunlight from entering the room. In intermediate seasons, opening both sides of windows induces a cooling effect via natural ventilation in the living room. By closing the windows on both sides in winter, the loggia becomes a thermal buffer space and prevents heat loss. In addition, a loggia with a large, single-paned glass window is effective for obtaining solar heat as a sunroom.

\subsection{Movable horizontal curtain}

Fig.6 shows the position of the movable horizontal curtain and the interior view when installing it. The curtain is a polyester roll screen stretched along a steel beam and improved the air conditioning efficiency by reducing the required air volume.

\subsection{Heat insulation blinds and heat shield blinds}

Heat insulation blinds using a honeycomb air layer were installed on all windows in the high-insulation walls to improve performance. A heat shield blind was installed in the large windows in existing low-insulation walls to prevent excessive solar radiation from entering the loggia.

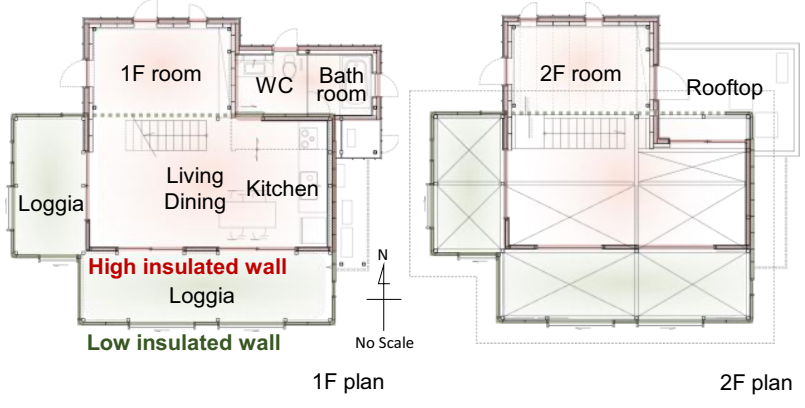

Fig.2 Floor plan of the experimental house

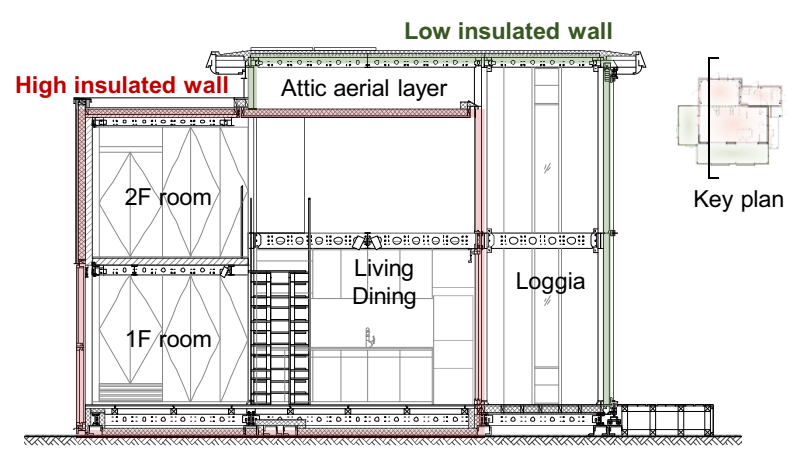

Fig.3 Short section of the experimental house

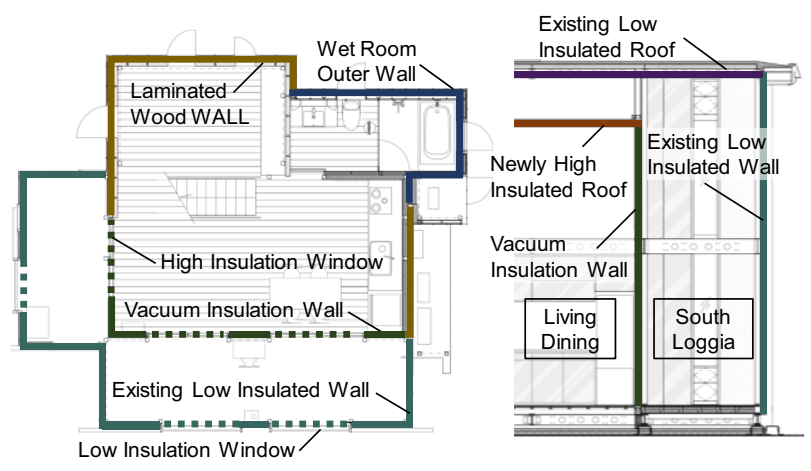

Fig.4 Arrangement of each member

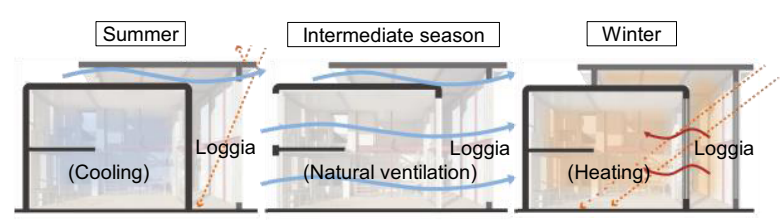

Fig.5 Seasonal operation of loggia
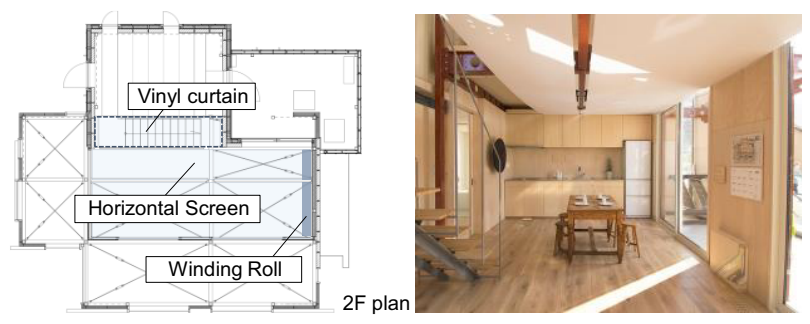

Fig.6 Installation position of the movable horizontal curtain

\section{Measurement Outlines}

Actual measurement of the thermal environment was carried out during the ENEMANE House 2017 competition from Nov. 18, 2017 to Nov. 21, 2017, and from Nov. 24, 2017 to Nov. 28, 2017. 


\subsection{Measurement outlines}

From 9: 00 to 12: 00 and 14: 00 to 18: 00 , three students were in the experimental house as a human load and carried out special tasks and equipment operation.

\subsection{Measurement items and target values}

Table 3 shows the target values of the indoor environment, Table 4 shows the measurement items, and Fig. 7 shows the measurement points. We aimed to operate the equipment so that the indoor environment remained within the target value range designated by the secretariat of the measurement competition.

\subsection{Operating conditions}

\subsubsection{Windows and Blinds}

Fig. 8 shows the operation schedule of the facilities. The windows remained closed except when instructed otherwise. All insulation blinds closed except for those inside the loggia. The insulation blinds inside the loggia were opened from 10:00 to 15:00 for daylight introduction and closed after 15:00. The heat shield blinds were generally opened from 10:00 to 15:00 and closed at other times when there was little solar radiation. During the actual measurement period, all movable horizontal curtains were laid, and a temporary vinyl curtain was placed on the stairs.

\subsubsection{Air conditioner and total hear exchanger}

We used an air conditioner with heating capacity of 2.5 $\mathrm{kW}$. The temperature for the hours of 18:00 to 8:00 was set to $23{ }^{\circ} \mathrm{C}$. This was also the case when the air temperature did not reach the target value. We used a total heat exchanger with the outlet as the $1 \mathrm{~F}$ room. It performed at airflow rate of $160 \mathrm{~m}^{3} / \mathrm{h}$, at which ventilation frequency was 0.5 times $/ \mathrm{h}$ or more in the occupied time.

Table 3. Target values of the indoor environment

\begin{tabular}{|c|c|}
\hline Air temperature & $21.2-25.2{ }^{\circ} \mathrm{C}$ \\
\hline Relative humidity & $40-70 \%$ \\
\hline CO2 concentration & Less than $800 \mathrm{ppm}$ \\
\hline Illuminance(10:00 15:00) & $\begin{array}{c}\text { Ratio of the horizontal level } \\
\text { illuminance of the room to the total } \\
\text { sky illuminance is } 4 \% \text { or more }\end{array}$ \\
\hline Illuminance(15:00 18:00) & 200 lx or more in the living room \\
\hline
\end{tabular}

Table 4. Measurement items

\begin{tabular}{|c|c|c|}
\hline & $\begin{array}{l}\text { Measurement points / } \\
\text { Measurement height }\end{array}$ & $\begin{array}{c}\text { Measurement } \\
\text { interval }\end{array}$ \\
\hline Air temperature & \multirow{3}{*}{$\begin{array}{c}\text { Living room }(0.1,1.1,2.1,3.1 \mathrm{~m}) \\
\text { Kitchen, } 1 \mathrm{~F} \text { room, Toilet, South } \\
\text { loggia }(0.1,1.1 \mathrm{~m}) \\
\text { West loggia, } 2 \mathrm{~F} \text { room, }(1.1 \mathrm{~m})\end{array}$} & \multirow{3}{*}{$1 \mathrm{~min}$} \\
\hline Relative humidity & & \\
\hline & & \\
\hline $\mathrm{CO}_{2}$ concentration & Living room, $1 \mathrm{~F}$ room $(1.1 \mathrm{~m})$ & $1 \mathrm{~min}$ \\
\hline Illuminance & Living room & - \\
\hline
\end{tabular}

Table 2. Members' constitutions and performance values

\begin{tabular}{|c|c|c|}
\hline & Composition & $\begin{array}{c}U \text { value } \\
{\left[\mathbf{W} / \mathbf{m}^{2} \cdot \mathbf{K}\right]}\end{array}$ \\
\hline $\begin{array}{l}\text { Vacuum } \\
\text { Insulation } \\
\text { Wall } \\
(105 \mathrm{~mm})\end{array}$ & $\begin{array}{l}\text { Veneer } \mathrm{t} 9.5 \\
\text { High-performance Phenolic Form } \mathrm{t} 25 \\
\text { Vacuum Insulation Panel } \mathrm{t} 20+\mathrm{t} 30 \\
\text { Sheet-type PCM } \mathrm{t} 3 \\
\text { Airtight Sheet } \\
\text { Veneer } \mathrm{t} 3+\mathrm{t} 5.5\end{array}$ & 0.05 \\
\hline $\begin{array}{l}\text { Laminated } \\
\text { Wood Wall } \\
(255 \mathrm{~mm})\end{array}$ & $\begin{array}{l}\text { Galvalume Steel Sheet t } 0.4 \\
\text { Structural Plywood t } 9 \\
\text { Moisture Permeable Waterproof Sheet } \\
\text { Structural Plywood t } 9 \\
\text { High-performance Phenolic Foam t } 105 \\
\text { Structural Plywood t } 9 \\
\text { Airtight Sheet } \\
\text { WOOD.ALC t } 105\end{array}$ & 0.15 \\
\hline $\begin{array}{l}\text { Wet Room } \\
\text { Outer Wall } \\
(252 \mathrm{~mm})\end{array}$ & $\begin{array}{l}\text { Galvalume Steel Sheet t } 0.4 \\
\text { Base Plywood t } 9 \\
\text { Moisture Permeable Waterproof Sheet } \\
\text { Structural Plywood t } 11.5 \\
\text { High-performance Phenolic Foam t } 60 \\
\text { Structural Plywood t } 11.5 \\
\text { High-performance Phenolic Foam } \mathrm{t} 45 \\
\text { Airtight Sheet } \\
\text { Veneer t5.5 }\end{array}$ & 0.18 \\
\hline $\begin{array}{l}\text { Existing Low } \\
\text { Insulated Wall }\end{array}$ & ALC Panel t75 & 1.85 \\
\hline $\begin{array}{l}\text { Newly High } \\
\text { Insulated Roof } \\
(120.5 \mathrm{~mm}) \\
\end{array}$ & $\begin{array}{l}\text { Veneer t5.5 White Painted } \\
\text { Veneer t } 9 \\
\text { High-performance Phenolic Foam t } 105\end{array}$ & 0.17 \\
\hline $\begin{array}{l}\text { Existing Low } \\
\text { Insulated Roof } \\
(120 \mathrm{~mm})\end{array}$ & $\begin{array}{l}\text { Polymer Waterproof Sheet } \\
\text { Fiberglass Cloth } \\
\text { Styrofoam t45 } \\
\text { ALC Panel t75 }\end{array}$ & 2.27 \\
\hline $\begin{array}{c}\text { Low Insulation } \\
\text { Window }\end{array}$ & $\begin{array}{l}\text { Aluminum Sash } \\
\text { Single Pane Glass }\end{array}$ & 6.51 \\
\hline $\begin{array}{c}\text { High Insulation } \\
\text { Window }\end{array}$ & $\begin{array}{l}\text { Sash of Aluminum and Resin } \\
\text { Gas-containing Low-E Triple Glass }\end{array}$ & 1.29 \\
\hline $\begin{array}{c}\text { Floor } \\
(457 \mathrm{~mm})\end{array}$ & $\begin{array}{l}\text { Flooring t15 } \\
\text { PCM } 30 \mathrm{~mm} \\
\text { High-performance Phenolic Foam t105 } \\
\text { Iron Plate }\end{array}$ & 0.16 \\
\hline
\end{tabular}

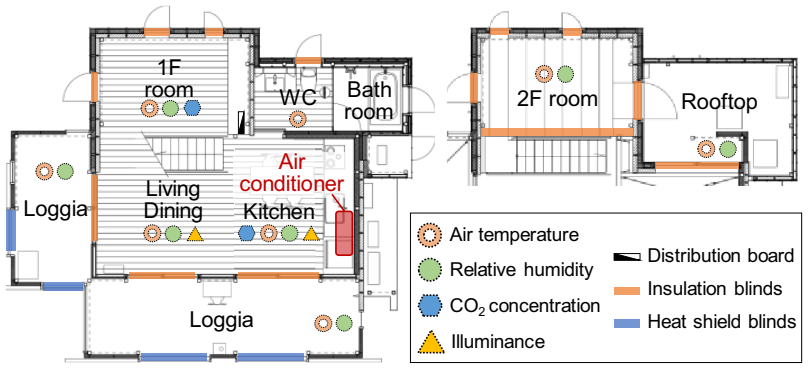

Fig.7 Measurement points

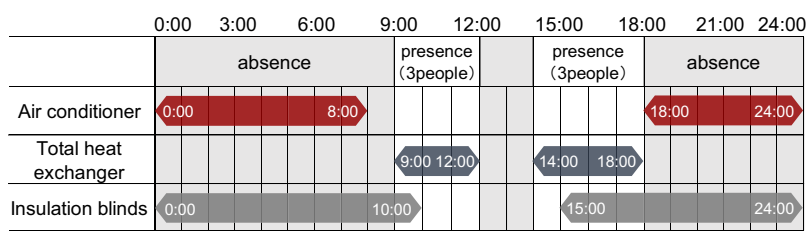

Fig.8 Operation schedule of the facilities 


\section{Results of proposed operation method for the loggia}

\subsection{Thermal environment evaluation of the loggia}

Figure 9 shows the time course of the air temperature on sunny and cloudy days. The air temperature of the loggia depended greatly on the amount of solar radiation, was observed to rise to approximately $30{ }^{\circ} \mathrm{C}$ depending on outside air conditions. On the other hand, the temperature declined to match the outside air temperature during times when solar radiation could not be captured (such as after sunset); however, we believe that owes to the influence of the inflow of outside air from the $2.5 \mathrm{~cm}$ gap between the outer wall of ALC panels and the large windows. Therefore, in order to use loggias as a thermal buffer spaces in winter, improvements in airtightness of loggia are required. In addition, it is necessary to take into consideration the heat insulation performance and heat capacity of loggias along with the physical properties of windows used for solar radiation acquisition.

\subsection{Environmental effects from opening and closing windows in loggia}

Figure 10 shows the time course of the air temperature; Figure 11 shows the time course of the $\mathrm{CO}_{2}$ concentration. On the 27th and 28th (sunny days), the hours of 11:00 to 12:00 and 14:00 to 15:00 showed temperatures in excess of $23{ }^{\circ} \mathrm{C}$. Thus, we conducted window operations and other environmental adjustments to mix air from the high insulation area with air in the south loggia. In addition, windows were closed and heat shield blinds were lowered from of 12:00 to 14:00 on the 27th to prevent overheating. Although it was not possible to confirm a rise in room temperature due to the warm air in the south loggia, it was confirmed that suppressing rises in $\mathrm{CO}_{2}$ concentration via ventilation could be performed without lowering the room temperature.

\section{Indoor environment evaluations}

Figure 12 shows time course of the PMV. We are assuming that mean radiant temperature is equal to air temperature, relative air velocity is $0.05 \mathrm{~m} / \mathrm{s}$, clothing is $0.6 \mathrm{clo}$, and metabolic rate is 1.1 met. During the actual measurement period, predicted mean vote [4] (PMV) showed a slightly cold side, fluctuating between -1 and 0 for most of the time in highly insulated area. The air temperature in the living room was maintained at the target value in $94 \%$ of the time, the relative humidity was $95 \%$ and the $\mathrm{CO}_{2}$ concentration was $99 \%$, thereby providing a comfortable living space. These target values were also maintained $99 \%$ of the time during illuminance of the living room.

\section{Conclusion}

In this paper, a $\mathrm{ZEH}$ renovation method for existing industrialized houses and the outline of an experimental house were described. Results showed that the thermal environment of the experimental house was comfortable and the operation planning in the loggia, which enabled the residents to adjust the living environment, was effective.

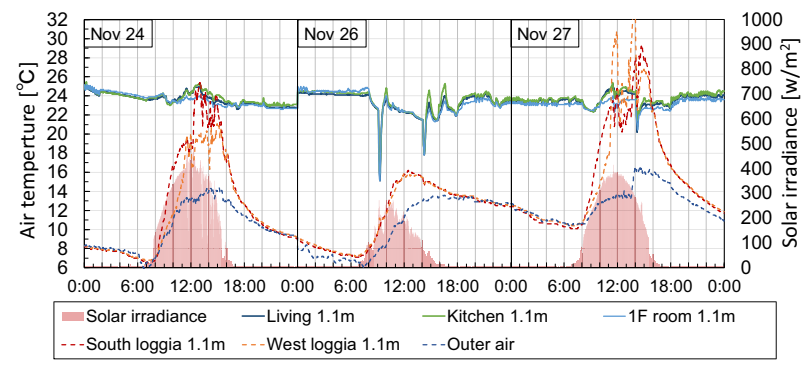

Fig.9 Time course of the air temperature on sunny and cloudy days

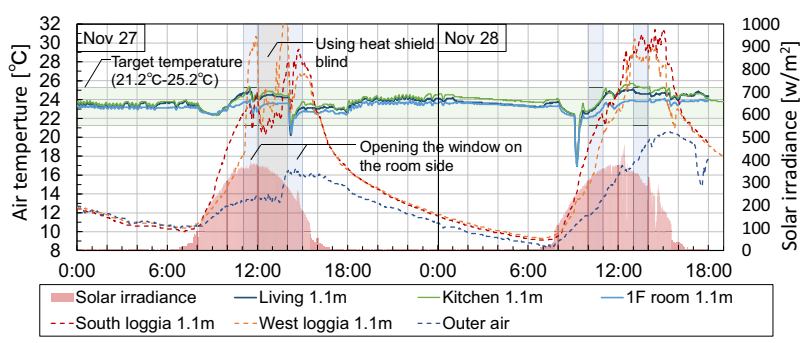

Fig.10 Time course of the air temperature

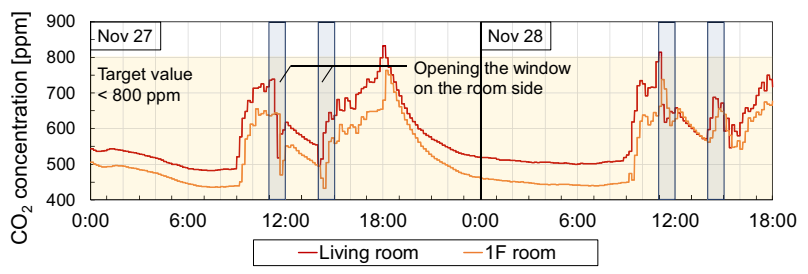

Fig.11 Time course of the $\mathrm{CO}_{2}$ concentration

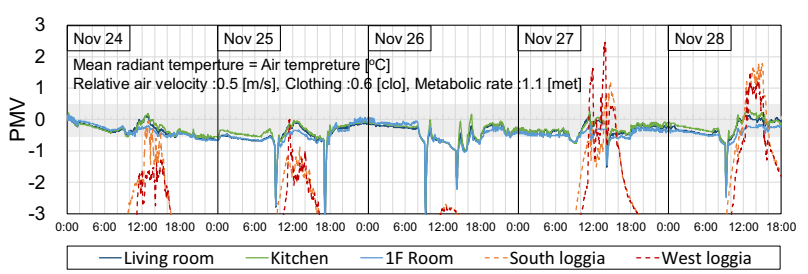

Fig.12 Time course of the PMV

\section{References}

1. Sustainable open Innovation Initiative, https://sii.or.jp/ zeh28 /file/doc_1122_2.pdf, [accessed 30.03.19]

2. JIS A 2101, Building components and building elementsThermal resistance and thermal transmittance-Caluculation method, 2003

3. JIS A 2102, Thermal performance of windows and doorsCalculation of thermal transmittance-Part 1:General, 2011

4. ISO 7730, Ergonomics of the thermal environmentAnalytical determination and interpretation of thermal comfort using calculation of the PMV and PPD indices and local thermal comfort ceiteria, 2005

\section{Acknowledgemnts}

This research result is obtained by "Enemane House 2017" implemented by Sustainable open Innovation Initiative (SII). Thank you very much for the people involved and the cooperating companies. In addition, We would like to thank Editage (www.editage.jp) for English language editing. 